May 2002 • NREL/CP-620-32430

\title{
A Certificate-Based Approach to Marketing Green Power and Constructing New Wind Energy Facilities
}

\section{Preprint}

\author{
E. Blank \\ Community Energy, Inc.
}

L. Bird and B. Swezey

National Renewable Energy Laboratory

To be presented at the American Wind Energy Association (AWEA) Windpower 2002 Conference Portland, Oregon

June 2-5, 2002

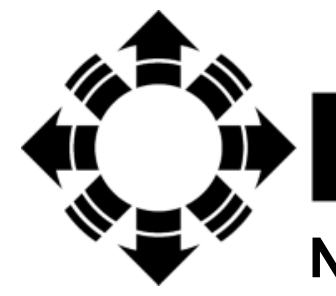

National Renewable Energy Laboratory

1617 Cole Boulevard

Golden, Colorado 80401-3393

NREL is a U.S. Department of Energy Laboratory

Operated by Midwest Research Institute $\bullet$ Battelle $\bullet$ Bechtel

Contract No. DE-AC36-99-G010337 


\section{NOTICE}

The submitted manuscript has been offered by an employee of the Midwest Research Institute (MRI), a contractor of the US Government under Contract No. DE-AC36-99G010337. Accordingly, the US Government and MRI retain a nonexclusive royalty-free license to publish or reproduce the published form of this contribution, or allow others to do so, for US Government purposes.

This report was prepared as an account of work sponsored by an agency of the United States government. Neither the United States government nor any agency thereof, nor any of their employees, makes any warranty, express or implied, or assumes any legal liability or responsibility for the accuracy, completeness, or usefulness of any information, apparatus, product, or process disclosed, or represents that its use would not infringe privately owned rights. Reference herein to any specific commercial product, process, or service by trade name, trademark, manufacturer, or otherwise does not necessarily constitute or imply its endorsement, recommendation, or favoring by the United States government or any agency thereof. The views and opinions of authors expressed herein do not necessarily state or reflect those of the United States government or any agency thereof.

Available electronically at http://www.osti.gov/bridge

Available for a processing fee to U.S. Department of Energy and its contractors, in paper, from:

U.S. Department of Energy

Office of Scientific and Technical Information

P.O. Box 62

Oak Ridge, TN 37831-0062

phone: 865.576 .8401

fax: 865.576.5728

email: reports@adonis.osti.gov

Available for sale to the public, in paper, from:

U.S. Department of Commerce

National Technical Information Service

5285 Port Royal Road

Springfield, VA 22161

phone: 800.553 .6847

fax: 703.605.6900

email: orders@ntis.fedworld.gov

online ordering: http://www.ntis.gov/ordering.htm

Printed on paper containing at least $50 \%$ wastepaper, including $20 \%$ postconsumer waste 


\title{
A Certificate-Based Approach to Marketing Green Power and Constructing New Wind Energy Facilities*
}

\author{
Eric Blank \\ Community Energy, Inc. \\ Lori Bird \\ Blair Swezey \\ National Renewable Energy Laboratory
}

\begin{abstract}
The availability of wind energy certificates in Pennsylvania's retail electricity market has made a critical difference in the economic feasibility of developing $140 \mathrm{MW}$ of new wind energy projects in the region. Certificates offer important benefits to both green power suppliers and buyers by reducing transaction barriers and thus lowering the cost of renewable energy. Buyers also benefit through the increased flexibility offered by certificate products. The experience described in this paper offers important insights for selling green power certificates and achieving new wind energy development in other areas of the country.
\end{abstract}

\section{Green Power Market Fundamentals}

For the first time, consumers have the ability to affect how electricity is generated through market-based purchase decisions. About $75 \%$ of U.S. electricity supply comes from either coal-fired or nuclear generation, with attendant environmental problems. Only $2 \%$ of the U.S. power mix is supplied from renewable energy sources (excluding hydropower). The availability of "green power" products empowers consumers to purchase electricity generated from renewable energy sources that are less damaging to the environment. Typically, consumers must pay a premium on their electric bills to receive green power.

The ability to market wind energy at a premium directly to interested retail customers can make a critical difference in bringing new wind energy supply online. For example, in the MidAtlantic region in the PJM Interconnection, ${ }^{1}$ wind-generated electricity currently costs between \$38-48 per megawatt-hour $(\mathrm{MWh})^{2}$ versus a cost range of $\$ 28-33 / \mathrm{MWh}$ for the conventional power sources that are displaced by wind. Thus, wind generated electricity is between $\$ 5$ 20/MWh more expensive than conventional alternatives based on current PJM wholesale market conditions. Given this fundamental economic reality, significant wind energy investments had not occurred in the Mid-Atlantic region prior to 2000.

\footnotetext{
* Presented at Windpower 2002, June 4, 2002.

${ }^{1}$ The PJM Interconnection is responsible for the operation and control of the bulk electric power system throughout major portions of five Mid-Atlantic states and the District of Columbia.

${ }^{2}$ Represents levelized cost range in nominal terms, assuming availability of a long-term power purchase contract, the availability of the federal production tax credit, and some limited public funding support.
} 
If customers are willing to pay a premium to purchase wind energy, however, the fundamental economic reality is altered. Indeed, experience now suggests that with the right marketing approaches, there is a broad segment of both residential and commercial customers willing to pay premiums of $\$ 15-25 / \mathrm{MWh}$ to purchase locally generated wind energy. This premium more than offsets the above-market costs of wind energy in wholesale markets.

There are two distinct markets for green power in the United States. In regulated markets, a single utility may provide a green power option to its customers through "green pricing," an optional service or tariff through which customers can support a greater level of utility company investment in renewable energy technologies. ${ }^{3}$ Many utilities offer green pricing to build customer loyalty and expand business lines and expertise. More than 95 utilities in 31 states offer green pricing or are in the process of preparing programs and, in several instances, these programs have led to significant new wind energy development. ${ }^{4}$

In restructured or competitive electricity markets, electricity customers can choose from among multiple electricity suppliers, some of which may offer green power. Electricity markets are open to competition in nearly a dozen states. A number of other states are phasing in competitive choice by allowing some customers to choose their electricity supplier. To date, competitive marketers have offered green power to retail or wholesale customers in California, Illinois, New Jersey, New York, Pennsylvania, Texas, and several other Mid-Atlantic and New England states.

However, a new type of green power product supplied from "renewable energy certificates" is emerging. The certificates represent the environmental attributes of renewable energy generation and can be sold to customers in either type of market, whether or not they already have access to a green power product from their existing retail power provider. Wind energy certificates represent one type of renewable energy certificate.

\section{Wind Energy Benefits}

Like other renewable energy sources, wind energy has several types of benefits, which are not easily quantifiable in the electric power marketplace. First, wind energy provides environmental benefits because it produces no air pollutant emissions. When wind energy is generated and fed into the grid, less energy is generated from other sources, which may include coal, gas, and oil-fired plants. Depending on unit dispatch patterns, reduced generation from these fossil fuel power plants will result in lower emissions of nitrogen oxide $\left(\mathrm{NO}_{\mathrm{X}}\right)$, sulfur dioxide $\left(\mathrm{SO}_{2}\right)$, mercury, and carbon dioxide $\left(\mathrm{CO}_{2}\right)$.

\footnotetext{
${ }^{3}$ Green pricing is also offered by municipalities, rural electric cooperatives, and other publicly owned utilities, which, although not necessarily regulated, have exclusive service territories.

${ }^{4}$ More than $80 \%$ of the renewable energy capacity installed for green pricing programs is wind energy. (See: http://www.eren.doe.gov/greenpower/new_gp cap.shtml) Nevertheless, NREL has found that only a handful of utilities are responsible for the bulk of this development. Most utility programs have resulted in less than $2 \mathrm{MW}$ of new renewables development. See Swezey and Bird, Utility Green Pricing Programs: What Defines Success? National Renewable Energy Laboratory, September 2001. (http://www.eren.doe.gov/greenpower/29831.pdf)
} 
The emission reductions resulting from new wind energy projects can have real and quantifiable economic value, although the value explicitly recognized in electricity markets has been modest to date. A statute contained in the 1990 Clean Air Act Amendments explicitly provides for a limited number of tradable $\mathrm{SO}_{2}$ allowances for renewable energy projects. ${ }^{5}$ And a process currently underway with the Western Regional Air Partnership to reduce $\mathrm{SO}_{2}$ emissions in the western United States proposes to provide emission reduction allowances for renewable energy projects. ${ }^{6}$ With appropriate regulatory treatment, these allowances could be sold in the context of a national or regional trading system to create tangible financial benefits for the allowance owners.

In the future, the value of emissions reductions created from new wind energy facilities may be more liquid and substantially larger. Increasingly, credits for emission reductions from renewable energy sources are being included in State Implementation Plans (SIPs). ${ }^{7}$ Likewise, a national four-pollutant bill (covering $\mathrm{CO}_{2}, \mathrm{SO}_{2}$, mercury, and $\mathrm{NO}_{\mathrm{X}}$ ) could also create emission reduction credits for renewable energy sources. ${ }^{8}$ Indeed, a number of European countries already have mechanisms in place that allocate $\mathrm{CO}_{2}$ emission credits and allowances to renewable generation sources. As such, the property rights to these emission reductions and allowances can be sold and transferred separately from the underlying electricity.

In addition to the emission reductions resulting from greater use of renewable resources, there are also risk diversification and domestic energy security benefits. By commercializing new technologies, such as wind energy, the overall electric supply mix becomes more diversified and less subject to fuel price increases and tighter environmental regulation on fossil fuel plants. These risk diversification benefits of renewable resources have just begun to generate economic value to generators as a result of state-based renewable portfolio standards. This value is a property right that can be distinguished and conveyed separately from the electricity generated from the wind energy facility.

\section{Wind Energy Certificates}

The concept behind wind energy certificates is simple. ${ }^{9}$ As a clean, renewable source of power, wind energy facilities both generate electricity and produce environmental and other benefits that have economic value that can be distinguished from the underlying value of the electrical generation. As discussed above, the non-electrical attributes involve environmental, risk diversification, energy security and price stability benefits. These attributes of renewable

\footnotetext{
${ }^{5}$ David Wooley, A Guide to the Clean Air Act for the Renewable Energy Community, Renewable Energy Policy Project, 2000, section 3, page 8 (noting shortcomings in the Clean Air Act for promoting renewables). See http://www.repp.org/repp_pubs/articles/issuebr15/caaRen.pdf.

${ }^{6}$ See http://www.wrapair.org/.

${ }^{7}$ Under the Clean Air Act, states are required to develop emissions control strategies for criteria pollutants $\left(\mathrm{SO}_{2}, \mathrm{NO}_{\mathrm{X}}\right.$, ozone, particulate matter, carbon monoxide, and lead).

${ }^{8}$ See generally Credit Trading and Wind Power: Issues and Opportunities, National Wind Coordinating Committee, January 15, 2001, which provides a summary of the literature on credit trading from renewable energy projects. (http://www.nationalwind.org/pubs/credit/credit_wind.pdf)

${ }_{9}$ In some markets, wind energy certificates may also be known as tradable renewable credits (TRCs), renewable energy certificates (RECs), or green tags.
} 
energy generation have real and quantifiable economic value, which can be priced and conveyed separately from the electrical commodity.

A wind energy certificate simply represents the contract right to claim or separately transfer the economic value or premium associated with the environmental and other nonelectrical attributes of a wind energy facility. As such, certificates provide individual customers with the opportunity to purchase the current and future value of the emissions reduction and other non-electrical benefits of these facilities for a fixed term.

In fact, the concept behind renewable energy certificates, i.e., that the renewable energy attributes can be valued and tracked separately from the electricity delivered to the grid from renewable facilities, is the basis for most green power sales, wholesale or retail, now occurring in the market. This is because all grid-tied customers receive their power from the same sources. All of the generation sources in a particular power pool are combined and balanced hourly to meet total customer load. Traditional green power providers simply account for the amount of power produced from each renewable resource, making sure that enough power is being generated from these sources to meet the subscribed loads of its green power customers. ${ }^{10}$

Similarly, certificate providers track the power generation from wind energy facilities and account for this generation in the form of certificates that represent discrete amounts of generation, typically in increments of one megawatt-hour. Figure 1 shows a hypothetical example of a certificate transaction. ${ }^{11}$

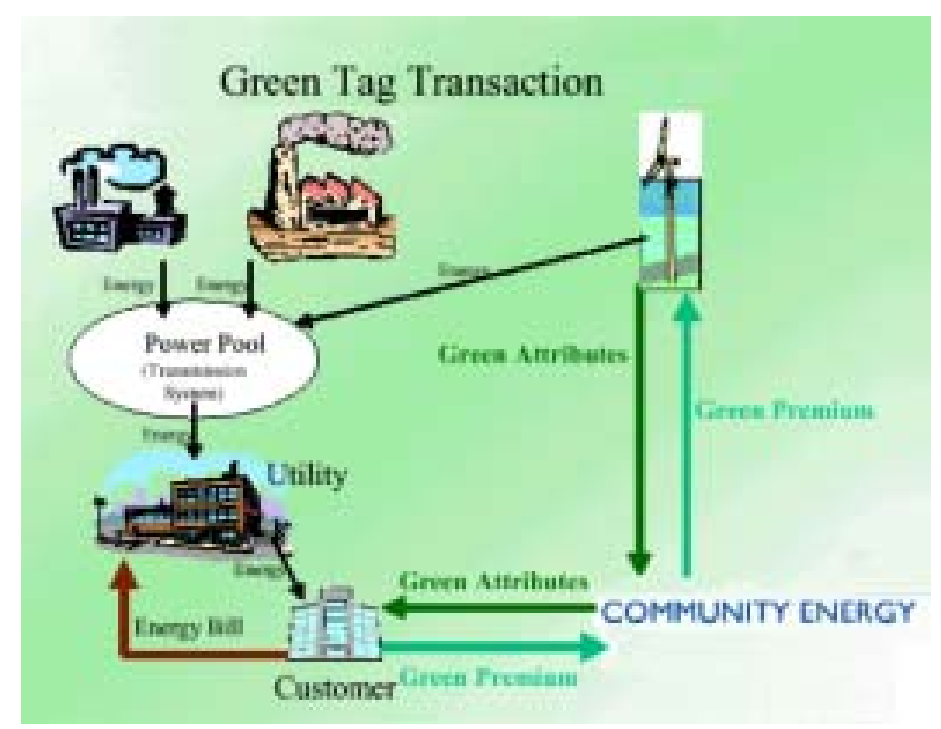

Figure 1 - Example of a Certificate Transaction

\footnotetext{
${ }^{10}$ The Center for Resource Solutions operates several programs to verify the green power sales of participating utilities and marketers. (See http://www.resource-solutions.org/programs.htm.)

${ }^{11}$ Figure 1 is adapted from materials developed by the Bonneville Environmental Foundation.
} 
Without certificate tracking of renewable energy, delivery of wind energy to end-use electric customers requires: (1) finding and scheduling a unique transmission pathway from the wind generator to the end-use customers; (2) "firming" the wind energy supply to match the customers' load profiles; (3) having different retail suppliers take title to the wind generated electricity for their blocks of customers; and (4) having the retail supplier separately allocate the green power cost on customers' bills. Each of these steps represents one or more complex transactions that adds to the final product cost.

In contrast, certificates can be provided to individual customers with minimal transaction costs. Certificate contracts — often less than five pages — can be negotiated and executed in a matter of weeks. The electricity commodity generated by the wind plant can be delivered to the grid at the most advantageous points without concern for matching customer loads. Customers simply pay for the value of the renewable energy attribute that is created over some period of time.

Despite the potential of certificates to significantly expand wind energy generation, there are some issues related to general consumer acceptance of certificate products. First, the environmental benefits of renewable power purchases could become less tangible to some consumers if the generation is located far from the customer; the extent to which consumers will purchase certificates created from projects beyond their immediate region of concern is unknown. Second, customers may receive two billing statements, one from their incumbent electricity supplier and the other from the renewable certificate supplier. Finally, some type of tracking system is required to verify certificate supplier claims to prevent double sales and other potential market abuses.

\section{A Pennsylvania Case Study}

Community Energy, Inc. (CEI), a for-profit, renewable energy marketing and development company, negotiated and executed a co-marketing agreement with Exelon Generation Company (EGC) to market wind energy procured by EGC to end-use electric customers. Under the agreement, EGC enters into long-term arrangements with third-party developers and owners for wind energy as long as CEI can find retail end-use customers to purchase the wind energy. The wind energy is marketed in the form of wind energy certificates that represent the entire bundle of attributes associated with wind power generation. Figure 2 illustrates this institutional relationship.

During 2001, CEI was successful in marketing wind energy certificates to a number of large customers in Pennsylvania. The following discussion documents some of the unique benefits of certificates that contributed to these sales.

\section{Carnegie Mellon University}

In May 2001, Carnegie Mellon became the first university in Pennsylvania to make a green power commitment when it agreed to purchase wind energy certificates representing $5 \%$ of its total electricity load-about 4.8 million $\mathrm{kWh}$ annually. 


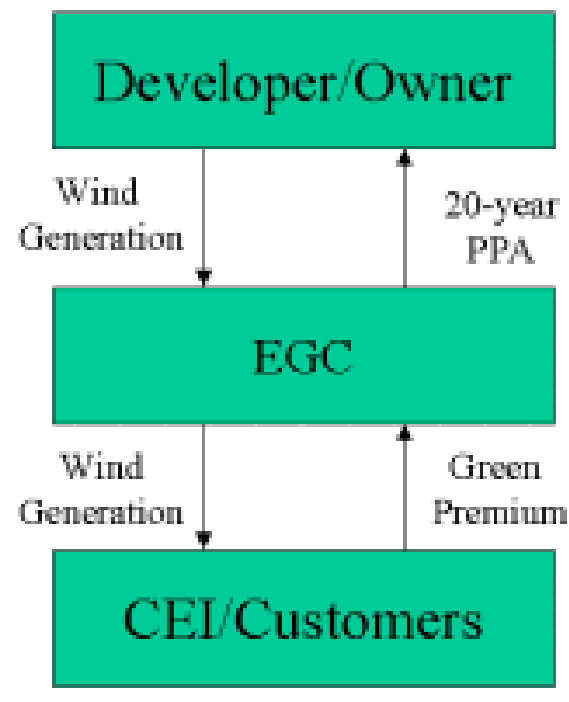

Figure 2 - Institutional Arrangement for Wind Energy Certificate Sales

The university first considered green power as it was preparing to re-bid its energy supply contract. At that time, Environmental Defense, a non-profit environmental organization, brought renewable energy purchase options to the attention of the university's Green Practices Committee. The committee was established in 1998 to develop a more comprehensive waste reduction and energy conservation program at the university. After evaluating several renewable energy bids, the committee - comprised of students, faculty, and staff-recommended the certificates purchase to the administration as the "best buy environmentally" because the certificates represented $100 \%$ new wind energy from a locally sited facility. Also, the university was able to specify a wind purchase amount equivalent to a portion of its load. The president of the university and other high level administrators were supportive throughout the process and approved the purchase.

Although the certificates purchase will cost approximately $\$ 80,000$, the university chose to invest in wind energy certificates to:

- demonstrate the university's recognition of the importance of development of renewable, less environmentally damaging sources of energy,

- provide educational opportunities for students, faculty and staff, and

- help support the development of wind power generation in Western Pennsylvania. ${ }^{12}$

Carnegie Mellon is planning a "university challenge" to encourage students, faculty and staff to conserve energy to help cover the extra cost of the certificates purchase.

${ }^{12}$ Carnegie Mellon, Background on Carnegie Mellon Wind Energy Initiative, Green Practices Committee, 2001. (http://www.cmu.edu/epc/back.htm) 


\section{Giant Eagle}

Giant Eagle, a 71-year-old, Pittsburgh-based grocery store chain, entered into an agreement last fall to purchase wind energy certificates to meet about $3 \%$ of the electricity consumption at its Pittsburgh stores. The total annual purchase is nearly three million $\mathrm{kWh}$.

The company first considered wind energy after hearing about the purchase by nearby Carnegie Mellon University. After evaluating other renewable energy purchase options, Giant Eagle opted for the wind energy certificates because the local project was highly visible in the community and provided tangible environmental benefits. The certificate product also enabled the company to purchase wind energy for only a portion of its total load, making the cost manageable within budget constraints. Despite the higher cost, the company was motivated by an interest in being a leader in supporting clean alternative fuels, protecting the environment, supporting the local economy, and enhancing national energy security.

\section{Penn State University}

In November 2001, Penn State University entered into a five-year contract with CEI to purchase wind energy certificates equivalent to $5 \%$ of the load of the University Park Campus. Under the agreement, the university will purchase 13.2 million $\mathrm{kWh}$ of certificates annually, representing the annual output of more than three, 1.5-MW wind turbines.

The purchase grew out of a meeting of the Campus Energy Program in June 2001, in which a committee agreed that the university "had a role to play in helping the emerging renewable energy market." 13 A clean energy purchase was also consistent with both the Governor's goal of having state facilities purchase green power and the objective of the university's Environmental Strategy Initiative to conduct "its business in a manner that demonstrates a commitment to environmental stewardship, and to move the University toward sustainable practices."14

After evaluating various green power purchasing options, the campus energy manager determined that wind energy certificates were the least-cost renewable energy option. In the proposal to the administration, the benefits of the purchase were enumerated as follows. A certificates purchase would:

- allow the university to continue to shop its retail electric accounts in the competitive market to obtain the lowest price,

- offset coal and other fossil fuel generation emissions in the state because the wind project was located in Pennsylvania,

- $\quad$ support the Pennsylvania economy, and

\footnotetext{
${ }^{13}$ Penn State University, Office of Physical Plant, PA Wind Power Procurement, March 2002. (http://energy.opp.psu.edu/energy/Procure/windpwr.htm)

${ }^{14}$ Penn State University, Finance \& Business Department, Environmental Strategy. (http://www.opp.psu.edu/f\&benvstrategy)
} 
- position the university as a leader in promoting clean energy. ${ }^{15}$

It was also determined that certificates would cost half as much as purchasing directly from a retail green power supplier.

The university was able to pay the extra cost of the wind power through its existing facilities budget. There are also plans to purchase certificates from an additional turbine to offset $5 \%$ of the electricity consumption at satellite campuses.

\section{University of Pennsylvania}

The University of Pennsylvania (Penn) became the largest wind energy supporter in the state when it signed a contract to purchase wind energy certificates representing about 20 million $\mathrm{kWh} /$ year of wind power (about 7.6 MW).

Penn students initiated the effort by bringing green power to the attention of the university's Strategic Utilities Group, which is responsible for energy-related matters on campus. Negotiating a contract was a collaborative process in which the students provided research support and assisted the committee in evaluating proposals. The university had not attempted to purchase green power in previous competitive energy solicitations.

The Facilities Operations Group proceeded with the wind power purchase to demonstrate the university's desire to be a responsible citizen and an environmental steward. The group found the certificates appealing because of their flexibility and because they were generated from a new wind energy project located within the state. The purchase was undertaken in part because of strong support from faculty and students and an interest in reducing the university's overall air pollutant emissions - the Philadelphia campus is located within an EPA-designated air quality non-attainment area. The university, which is one of the largest employers in the Philadelphia area, hopes that air quality regulators will view the purchase as a "good faith" effort to reduce emissions and that it will be able to obtain air pollutant emissions credits in the future. In this way, the university views the certificates purchase as an investment.

\section{Lessons Learned from the Pennsylvania Market}

For large purchasers, in particular, one of the primary benefits of a certificate-based green power transaction is the flexibility provided for power procurement. Renewable energy certificates enable a company or organization to more easily purchase green power to offset a portion of its electricity load without having to switch the entire load to a renewable provider. In addition, because they are not required to switch electricity providers, certificate purchasers retain the ability to select the least-cost electricity provider in the competitive market and, at the same time, support renewable energy development. For at least two of the organizations, the wind energy certificates were essentially the only viable renewable energy option available.

\footnotetext{
${ }^{15}$ Supra, Note 13.
} 
A common motivation, among the organizations interviewed, was an interest in obtaining power from a locally sited facility. The wind energy certificates product offered by CEI was attractive because it provides the contractual means to support a wind project in Western Pennsylvania. For one of the universities, the location of the facility was important because the nearby facility could provide educational opportunities for its faculty, staff, and students. Finally, some purchasers noted that the local economic benefits from the construction and on-going maintenance of the turbines were an added benefit.

Other purchase motivations included an interest in being a leader in supporting clean energy and gaining a positive image in the community. Most found that the visibility of the instate project provided "tangible benefits" to the community.

Finally, virtually all of the purchasers were interested in the air quality benefits from offsetting fossil fuel generation with wind. One purchaser was specifically interested in potential future emissions credits that might be derived from the wind energy purchase.

\section{Conclusions}

In both regulated and competitive markets, renewable energy certificates provide an important tool for facilitating green power deals and promoting new wind energy development. Certificate products have premium value in the market because renewable energy produces no pollution and is not fuel dependent.

The availability of wind energy certificates in Pennsylvania's retail electricity market has led directly to the development of $140 \mathrm{MW}$ of new wind energy projects in the region. The case studies presented here demonstrate that certificates have provided tangible benefits to wind power generators and customers by reducing transaction costs, introducing flexibility into purchase decisions, and providing for the development of local wind resources with resulting environmental benefits. 


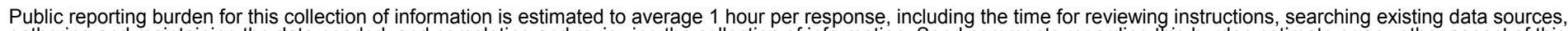

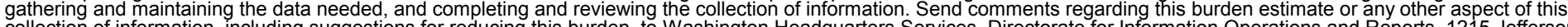
Davis Highway, Suite 1204, Arlington, VA 22202-4302, and to the Office of Management and Budget, Paperwork Reduction Project (0704-0188), Washington, DC 20503.

\begin{tabular}{|l|l|l|} 
1. AGENCY USE ONLY (Leave blank) & $\begin{array}{l}\text { 2. REPORT DATE } \\
\text { May } 2002\end{array}$ & $\begin{array}{l}\text { 3. REPORT TYPE AND DATES COVERED } \\
\text { Conference Paper }\end{array}$ \\
\hline
\end{tabular}

\section{TITLE AND SUBTITLE \\ A Certificate-Based Approach to Marketing Green Power and Constructing New Wind}

Energy Facilities: Preprint

5. FUNDING NUMBERS

6. AUTHOR(S)

E. Blank, L. Bird, and B. Swezey

7. PERFORMING ORGANIZATION NAME(S) AND ADDRESS(ES)

National Renewable Energy Laboratory

TA: AS72-1006

1617 Cole Blvd.

Golden, CO 80401-3393

9. SPONSORING/MONITORING AGENCY NAME(S) AND ADDRESS(ES)

National Renewable Energy Laboratory

1617 Cole Blvd.

Golden, CO 80401-3393

8. PERFORMING ORGANIZATION REPORT NUMBER

\section{SUPPLEMENTARY NOTES}

NREL Technical Monitor: Walter Short

12a. DISTRIBUTION/AVAILABILITY STATEMENT

National Technical Information Service

U.S. Department of Commerce

5285 Port Royal Road

Springfield, VA 22161

ABSTRACT (Maximum 200 word). The availability of wind energy certificates in Pennsylvania's retail electricity market has made a critical difference in the economic feasibility of developing $140 \mathrm{MW}$ of new wind energy projects in the region.

Certificates offer important benefits to both green power suppliers and buyers by reducing transaction barriers and thus lowering the cost of renewable energy. Buyers also benefit through the increased flexibility offered by certificate products. The experience described in this paper offers important insights for selling green power certificates and achieving new wind energy development in other areas of the country.

14. SUBJECT TERMS

wind energy, certificates, American Wind Energy Association, Wind Energy Conference, green power marketing, Community Energy, Pennsylvania, emission reductions, Giant Eagle, Penn State University

17. SECURITY CLASSIFICATION OF REPORT Unclassified
18. SECURITY CLASSIFICATION OF THIS PAGE Unclassified
19. SECURITY CLASSIFICATION OF ABSTRACT Unclassified
15. NUMBER OF PAGES 9

16. PRICE CODE

UL 